\title{
Безперервний професійний розвиток ^ікаря-стоматолога у 2022 році
}

\begin{abstract}
Резюме. У 2022 році атестація лікарів відбуватиметься відповідно до Наказу МОЗ України від 22.02.2019 р. № 446 «Деякі питання безперервного професійного розвитку лікарів» (зі змінами) та постанови Кабінету Міністрів України від 14 липня 2021 р. № 725 «Про затверджсення Положення про систему безперервного професійного розвитку медичних та фармацевтичних працівників», яка набирає чинності з 1 січня 2022 року. До 1 березня 2022 року лікарю-стоматологу необхідно скласти особисте освітнє портфоліо за результатами безперервного професійного розвитку (БПР) та підтвердити 50 балів. БПР працівників сфери охорони здоров'я здійснюється шляхом здобуття неформальної освіти під час проходження навчання на заходах БПР. В статті надана інформація щодо механізму нарахування балів БПР, проведення їх щорічної перевірки та підготовки до атестації.
\end{abstract}

Ключові слова: атестація лікарів; система безперервного професійного розвитку; формальна освіта; неформальна освіта

\section{Вступ}

Система безперервного професійного розвитку (БПР) - це сучасний підхід до професійного вдосконалення лікаря. Після завершення формальної освіти лікарі мають постійно розвивати свої компетенції. Принцип безперервного навчання фахівців сфери охорони здоров'я поширений серед розвинутих країн Європи, Америки та Азії, зокрема у Великій Британії, США, Польщі, Чехії, Швеції, Сінгапурі та інших державах.

У країнах, де переважає приватна лікарська практика, ліцензування включає безперервний професійний розвиток лікаря, що є обов'язковим для продовження медичної ліцензії. Це поняття було введене Всесвітньою федерацією медичної освіти у 2001 році замість терміна «безперервна медична освіта», який використовувався раніше [6, с. 28]. Всесвітня федерація медичної освіти виділяє три етапи підготовки медичних працівників. Після дипломної освіти відбувається післядипломне навчання в інтернатурі, резидентурі або на циклах спеціалізації, де лікарі отримують власне спеціальність.

Наступна фаза - безперервний професійний розвиток - це освіта, яка триває впродовж усього життя. БПР є професійним обов'язком кожного лікаря, його тривалість становить 30-40 років. Відповідальність за проведення БПР покладається на самого лікаря та професійні асоціації. Організація БПР у різних країнах суттєво відрізняється і не є дуже жорсткою навіть там, де лімітується підтвердженням права лікаря на продовження медичної практики один раз на 5-7 років [7, с. 425]. Наприклад, у Словенії формами БПР є читання лекцій або участь у конгресах, публікація наукових статей у журналах, участь у підготовці монографій або підручників; самостійне навчання за допомогою мультимедійних програм і вивчення наукової літератури з письмовими відповідями на конкретні запитання; пізнавальні екскурсії та відвідування певних наукових установ або лікувально-профілактичних закладів; участь у лекціях відомих учених або лікарів; доповіді щодо хворих у товариствах або на конференціях. Інформація про обсяг навчання, виконаного за програмою БПР, виражається у кредитних одиницях (КО). Для оновлення ліцензії лікар повинен набрати як мінімум 75 КО впродовж терміну дії попередньої ліцензії (7 років). За кожний рік володіння ліцензією лікар повинен набирати 15 КО. Лікарська палата Словенії видає дозволи на організацію семінарів, лекцій та інших форм БПР на основі програм і реко-

\footnotetext{
(c) «Oral and General Health», 2021

(c) Видавець Заславський 0.Ю. / Publisher Zaslavsky 0.Yu., 2021
}

Для кореспонденції: Катерина Пожевілова, Національний медичний університет імені 0.0. Богомольця, бульв. Т. Шевченка, 13, м. Київ, 02000, Україна; е-таil: redact@i.uа For correspondence: Kateryna Pozhevylova, Bogomolets National Medical University, T. Shevchenko boulevard, 13, Kyiv, 02000, Ukraine; e-mail: redact@i.ua 


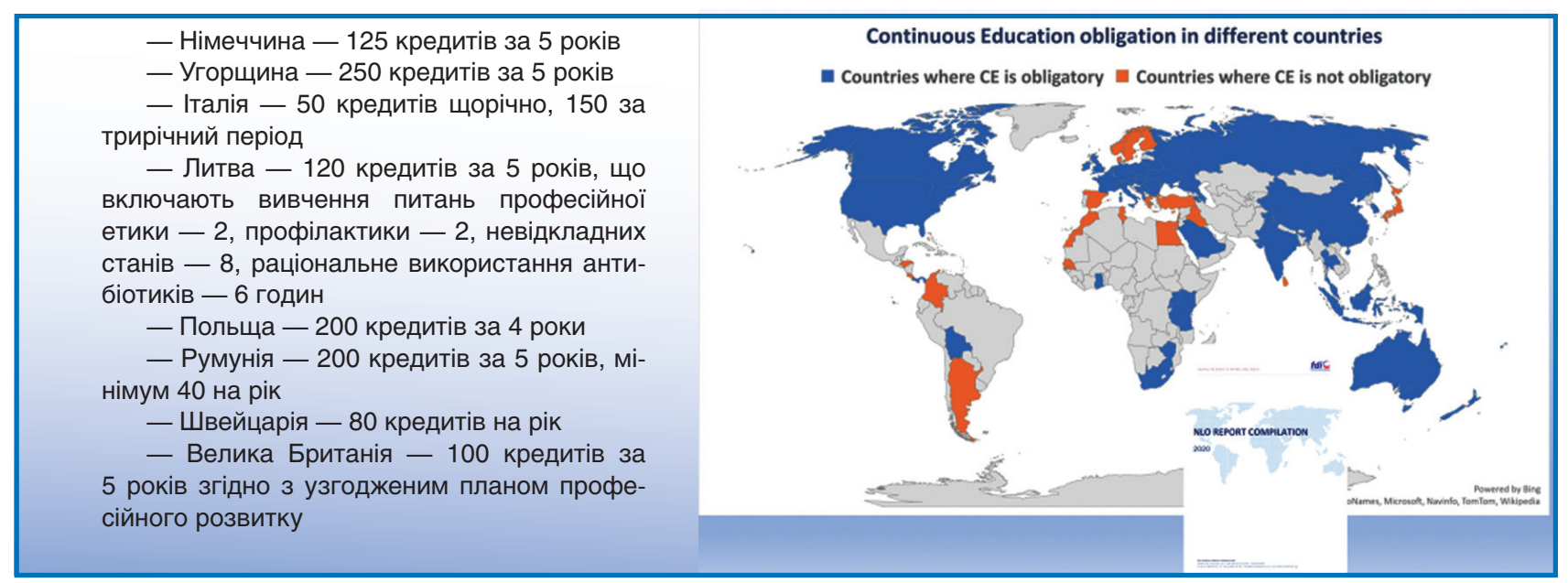

Рисунок 1. Безперервний професійний розвиток стоматологів країн Європи

мендацій лекторів. КО нараховуються за кожну годину читання лекції; за участь у конференції, семінарі, симпозіумі, у визнаних міжнародних форумах; за кожну написану статтю [7, с. 138-139].

В Україні починаючи з 1 січня 2020 року кожен лікар упродовж року має набрати щонайменше 50 балів БПР. Бали нараховуються за різні види навчання, які лікар вільно обирає на основі запропонованого МО3 України переліку видів діяльності. Загалом кількість балів не обмежена, проте щорічний обов'язковий мінімум становить саме 50 балів. Для лікарів, які значно перевищують кількісні й якісні вимоги до БПР, існує можливість позачергового отримання вищої категоpiï. Тобто для атестації у 2022 році лікар повинен подати до атестаційної комісії портфоліо за 2020 та 2021 роки, де загальна кількість балів повинна становити 100 балів і більше.

Лікар щороку вносить в освітнє портфоліо дані про своє навчання та засвідчує його в керівника свого закладу. Бали в портфоліо обліковуються згідно з додатком 5 до Порядку проведення атестації лікарів. Бланк освітнього портфоліо - це додаток 2 до цього ж Порядку.

\section{Нормативні Аокументи, що регулюють БПР ^ікаря-стоматолога в Україні}

Міністерство охорони здоров'я забезпечило внесення змін до наявної моделі безперервного професійного розвитку фахівців у сфері охорони здоров'я. Були враховані пропозиції медичної спільноти, а також розширені категорії працівників, які мають право на сучасний безперервний професійний розвиток.

Відповідну постанову «Про затвердження Положення про систему безперервного професійного розвитку медичних та фармацевтичних працівників» прийнято на засіданні уряду. Мета постанови - закріпити успішну світову практику розвитку медиків, що розпочалася в Україні з 2018 року, вдосконалити ії для формування системної та комплексної моделі навчання. БПР передбачає постійний розвиток працівників сфери охорони здоров'я для надання якісної медичної допомоги.

Нормативним актом про систему безперервного професійного розвитку медичних працівників є по- станова Кабінету Міністрів України № 725 від 14 липня 2021 р. У документі прописані лише основні засади здійснення безперервного професійного розвитку.

Лікарям, які здійснюють атестацію на присвоєння кваліфікаційної категорії (або її підтвердження), слід керуватися іншим нормативним документом - наказом МОЗ України № 446 від 22 лютого 2019 р. (у редакції наказу МО3 № 1753 від 18 серпня 2021 р.). Саме цей наказ слід роздрукувати та вивчити кожному лікарю. Окрім «Порядку проведення атестації лікарів» у документі наявні важливі додатки: атестаційний листок, особисте освітнє портфоліо, атестаційне посвідчення, критерії нарахування балів БПР.

Порада: роздрукуйте текст наказу № 446 з додатками. Завантажити можна за посиланням: https://zakon.rada.gov.ua/laws/show/z029319\#Text

\section{Атестація на присвоєння кваліфікаційної категорії}

Атестація лікарів на присвоєння кваліфікаційної категорії проводиться за спеціальностями як за основним місцем роботи, так і за сумісництвом один раз на п'ять років.

Кваліфікація лікарів-спеціалістів визначається атестаційною комісією за трьома кваліфікаційними категоріями:

- друга кваліфікаційна категорія присвоюється лікарям-спеціалістам, які мають необхідну кількість балів безперервного професійного розвитку та стаж роботи за певною спеціальністю понад п'ять років;

- перша кваліфікаційна категорія присвоюється лікарям-спеціалістам, які мають необхідну кількість балів безперервного професійного розвитку та стаж роботи за певною спеціальністю понад сім років;

- вища кваліфікаційна категорія присвоюється лікарям-спеціалістам, які мають необхідну кількість балів безперервного професійного розвитку та стаж роботи за певною спеціальністю понад десять років.

До стажу роботи для атестації за спеціальностями «терапевтична стоматологія», «хірургічна стоматологія», 
«ортопедична стоматологія», «ортодонтія», «дитяча стоматологія» зараховуються періоди роботи на посаді лікаря-стоматолога за умови відпрацювання за спеціальністю, з якої лікар атестується, не менше трьох років.

Лікарі, які бажають пройти атестацію на присвоєння кваліфікаційної категорії, подають до атестаційної комісії такі документи:

1) письмова заява;

2) атестаційний листок;

3) копії диплома, трудової книжки (за наявності) або витяг з реєстру застрахованих осіб Державного реєстру загальнообов'язкового державного соціального страхування, сертифіката лікаря-спеціаліста та/або посвідчення про наявність кваліфікаційної категорії (за наявності);

4) особисте освітнє портфоліо з результатами проходження безперервного професійного розвитку та копіями документів, що підтверджують обліковані бали безперервного професійного розвитку.

На засіданні атестаційної комісії лікар пред'являє оригінали документів, що підтверджують обліковані бали безперервного професійного розвитку, особисто.

\section{Атестація на піАтверАження кваліфікаційної категорії}

Лікарі, яким присвоєно кваліфікаційну категорію, проходять атестацію на іiї підтвердження один раз на п'ять років.

Атестація лікарів на підтвердження кваліфікаційної категорії проводиться за спеціальностями як за основним місцем роботи, так і за сумісництвом.

Лікарі, які бажають пройти атестацію на підтвердження кваліфікаційної категорії, подають до атестаційної комісії такі документи:

1) письмова заява;

2) атестаційний листок;

3) копії диплома, трудової книжки (за наявності) або витяг з реєстру застрахованих осіб Державного реєстру загальнообов'язкового державного соціального страхування, сертифіката лікаря-спеціаліста, посвідчення про наявність кваліфікаційної категорії;

4) особисте освітнє портфоліо з результатами проходження безперервного професійного розвитку та копіями документів, що підтверджують обліковані бали безперервного професійного розвитку.

\section{Щорічне навчання Аікарів - БПР}

Бали безперервного професійного розвитку нараховуються за здобуття формальної, неформальної та інформальної освіти у сфері охорони здоров'я:

- формальної освіти у сфері охорони здоров'я шляхом здобуття вищої освіти на освітньо-науковому та науковому рівні вищої освіти. Бали безперервного професійного розвитку за здобуття формальної освіти нараховуються лише за здобуття освітньо-наукового та наукового ступеня (доктор філософії, доктор наук);

- неформальної освіти - під час проходження: навчання на циклах тематичного удосконалення, професійного медичного стажування за межами закладу, де працює такий працівник; майстер-класу, симуляційного тренінгу або тренінгу з оволодіння практичними навичками, тренінгу, семінару, фахової (тематичної) школи, наукової та/або науково-практичної конференції (у тому числі конгресу, з'їзду, симпозіуму). Безперервний професійний розвиток шляхом здобуття неформальної освіти також може здійснюватися за дистанційною формою навчання з використанням електронних навчальних ресурсів. Дистанційне навчання у режимі реального часу передбачає, що присутність учасників може бути підтверджена та що вони мають можливість подавати свої запитання та відповіді;

- інформальної освіти - шляхом самоорганізованого здобуття працівниками сфери охорони здоров'я професійних компетентностей під час повсякденної діяльності, пов'язаної з професійною, громадською або іншою діяльністю. Підтвердженням безперервного професійного розвитку шляхом здобуття інформальної освіти може бути публікація статті або огляду в журналі, що має імпакт-фактор.

Нарахування балів здійснюється з розрахунком 1 бал за 2 години. Кількість годин за проходження курсу зазначена в описі курсу на платформі. Кількість балів, що враховуються до обов'язкового щорічного мінімуму, не має перевищувати 15 для україномовних та 20 для англомовних заходів.

Наприкінці попереднього року були внесені деякі зміни до Постанови Кабінету Міністрів № 302, згідно з якими вводиться нове поняття «електронна система безперервного професійного розвитку». Саме в ній будуть міститися всі дані про зареєстрованих провайдерів БПР, їхні заходи та учасників. Ще однією суттєвою зміною $є$ те, що проєкт нової постанови містить перелік вимог до заходів БПР і провайдерів. Останніми можуть вважатися фізичні та юридичні особи, які відповідають певним вимогам та зареєстровані в електронній системі. Зверніть увагу, що розширився список фахівців, на які поширюється постанова, - це лікарі, провізори та молодші спеціалісти з медичною освітою.

Усі лікарі, які здійснюють професійну діяльність, зобов'язані щороку подавати на перевірку особисте освітнє портфоліо та підтверджувати щонайменше 50 балів. Мінімальна кількість балів, яка має бути підтверджена за річний період, становить 50 (максимальна кількість балів необмежена).

Важливо! Наказом МО3 № 446 наведені критерії нарахування балів безперервного професійного розвитку.

Особисте освітнє портфоліо з результатами проходження безперервного професійного розвитку складається лікарем. Облік балів ведеться лікарем та засвідчується керівником закладу охорони здоров'я за місцем роботи у період, за який обліковуються бали.

Наявність мінімальної кількості балів, яка має бути підтверджена за річний період, не є обов'язковою, якщо у відповідний річний період лі- 
кар не обліковував бали або облікував менше 50 балів внаслідок виникнення об'єктивних причин (стан здоров'я лікаря, надзвичайні ситуації природного і техногенного характеру, військові дії тощо), підтверджених документально у встановленому законодавством порядку.

\section{Як реєструвати особисте ОсвітнЕ ПОРтФОАіо?}

Особисте освітнє портфоліо за відповідний річний період подається лікарем для щорічної перевірки до відділу кадрів за місцем роботи до 1 березня. Освітнє портфоліо подається щорічно виключно до відділу кадрів за місцем роботи незалежно від того, проходить лікар чергову атестацію у поточному році чи ні.

Особисте освітнє портфоліо містить:

- заповнену форму особистого освітнього портфоліо із зазначенням контактних даних (номер телефону, адреса електронної пошти);

- копії документів, що підтверджують обліковані бали безперервного професійного розвитку за відповідний річний період.

Зверніть увагу, що в особистому освітньому портфоліо є пункт «кількість наданих медичних послуг за звітний період».

Відділ кадрів за місцем роботи контролює вчасне подання лікарями їх особистих освітніх портфоліо та перевіряє, чи облікував лікар мінімальну кількість балів за відповідний річний період.

За результатами перевірки відділ кадрів за місцем роботи надає для затвердження керівнику закладу охорони здоров'я перевірені особисті освітні портфоліо, узагальнений звіт щодо подання лікарями особистих освітніх портфоліо та перелік осіб, які мають проходити атестацію у поточному році.

\section{Особиста віАповіАальність керівника}

Керівник закладу охорони здоров'я щорічно затверджує план навчання лікарів у рамках безперервного професійного розвитку та звіт щодо виконання плану за минулий рік.

Керівник закладу охорони здоров'я на підставі інформації, наданої відділом кадрів, приймає рішення щодо направлення лікаря на атестацію або на стажування, за що несе персональну відповідальність.
Пам'ятайте! Лікареві, який свідомо надав недостовірні дані про перебіг свого безперервного професійного розвитку, буде відмовлено в атестації.

\section{Висновки}

Отже, сучасний стан медичної сфери України потребує реформування. Аналіз вітчизняного та зарубіжного досвіду показує, що забезпечити та підвищити якість медичних послуг можливо тільки при постійному вдосконаленні та формуванні системи. БПР передбачає постійний розвиток працівників сфери охорони здоров’я для надання якісної медичної допомоги.

Конфлікт інтересів. Автори заявляють про відсутність конфлікту інтересів та власної фінансової зацікавленості при підготовці даної статті.

\section{Список мітератури}

1. Про затвердження Положення про систему безперервного професійного розвитку медичних та фармацевтичних працівників: Наказ МОЗ України № 725 від 14 липня 2021 року, що набирає чинності з 1 січня 2022 року. https://zakon.rada.gov.ua/laws/ show/725-2021-\%D0 \% BF\#Text

2. Деякі питання безперервного професійного розвитку лікарів: Наказ МОЗ України № 446 від 22.02.2019 року. https://zakon. rada.gov.ua/laws/show/z0293-19\#Text

3. Про внесення змін до наказу Міністерства охорони здоров’я України: Наказ МОЗ України № 1753 від 18.08.2021 року. https://zakon.rada.gov.ua/laws/show/z1338-21\#n2

4. Про затвердження Положення про систему безперервного професійного розвитку фахівців у сфері охорони здоров'я: постанови Кабінету Міністрів України від 28 березня 2018 року № 302. https://zakon.rada.gov.ua/laws/show/302-2018-\%D0\%BF\#Text

5. БПР лікарів: все що потрібно знати у 2021 році. Медичний nортал ITMED. https://itmed.org/clinik_articles/bpr-likariv-vseshcho-potribno-znati-v-2021-rotsi/

6. Про БПР. https://portal.phc.org.ua/uk/pro-bpr/

7. Худошина О.В. Зарубіжний досвід держсавного регулювання ліцензування професійної діяльності медичних працівників у контексті пропозицій реформування медичної сфери в Україні. Інвестиції: практика та досвід. 2017. № 20. C:/Users/user/ Desktop $/ 23 \% 20 \%$ !!!!!!!.pdf

Отримано/Received 02.12.2021 Рецензовано/Revised 17.12.2021 Прийнято до друку/Accepted 23.12.2021

\section{A. Pozhevilova'1, K. Pozhevilova ${ }^{2}$ \\ ${ }^{1}$ Gradalis Medical Center, Kyiv, Ukraine \\ 2Bogomolets National Medical University, Kyiv, Ukraine}

\section{Continuing professional development of a dentist in 2022}

Abstract. In 2022, attestation of doctors will take place in accordance with the Order of the Ministry of Health of Ukraine dated February 22, 2019 No. 446 "Some issues of continuous professional development of doctors" (as amended) and the Order of the Cabinet of Ministers of Ukraine dated July 14, 2021 No. 725 "On approval of the Regulations on continuous professional development of medical and pharmaceutical workers", which entered into force on January 1, 2022. By March 1, 2022, a dentist must complete a personal educational portfolio based on the results of continuing professional development (CPD) and confirm 50 points. CPD of healthcare workers is carried out through non-formal education during training at CPD events. The article provides information on the mechanism of scoring of CPD points, their annual inspection and preparation for certification.

Keywords: attestation of doctors; system of continuous professional development; formal education; non-formal education 